\title{
Border control and blurred responsibilities at the airport
}

Møhl, Perle

Published in:

Security Blurs

DOI:

$10.4324 / 9781351127387$

Publication date:

2019

Document version

Early version, also known as pre-print

Citation for published version (APA):

Møhl, P. (2019). Border control and blurred responsibilities at the airport. In T. Diphoorn, \& E. Grassiani (Eds.), Security Blurs: The Politics of Plural Security Provision (pp. 118-135). Routledge. Routledge Studies in Anthropology https://doi.org/10.4324/9781351127387 


\section{Border control and blurred responsibilities at the airport}

by Perle Møhl

Møhl, Perle (2019) 'Border control and blurred responsibilities at the airport'. In: Security Blurs: The Politics of Plural Security Provision. Diphoorn, T. \& Grassiani, E. (eds.). London: Routledge, s. 118-135.

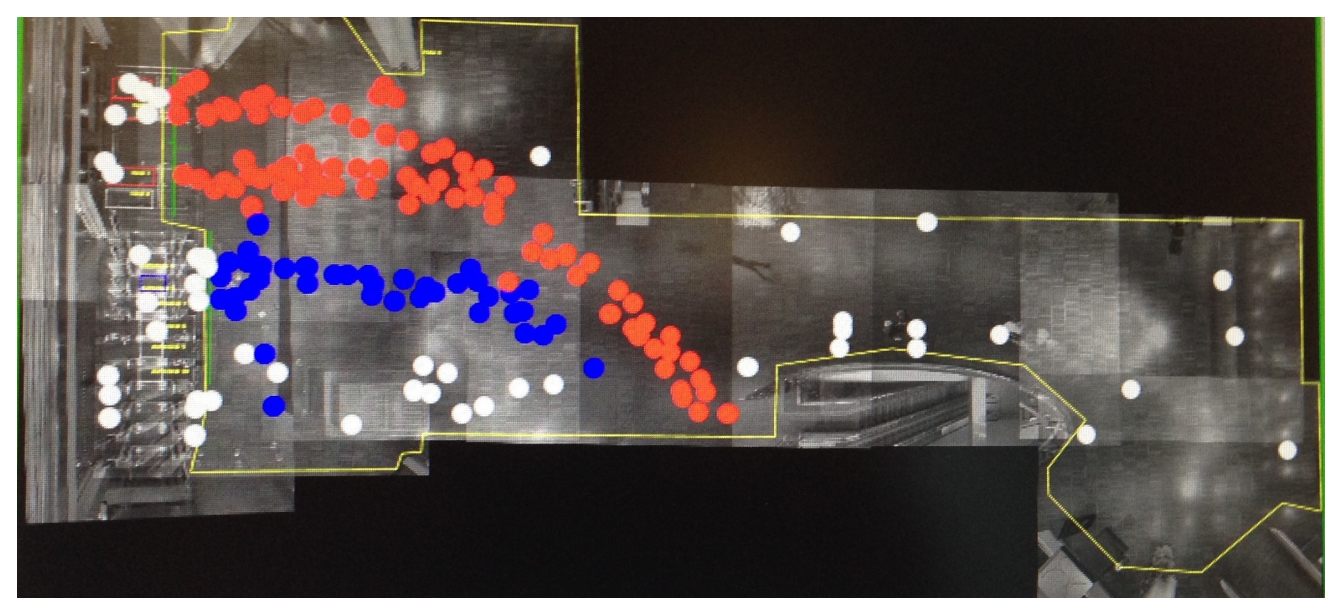

In the main office of the Border Police HQ of Copenhagen Airport, a screen presenting a black and white still-image of the border zone floor becomes animated when a person moves into the area. "3D people tracking sensors" in the ceiling identify a presence and a small white dot starts moving across the image. If the person queues up in front of the manual passport control, the dot turns bright red. If the person slows down by the ABC (Automated Border Control), the dot turns blue. White is movement, movement is good. At present, the many red and blue dots have turned into big blobs, indicating that too many people are queuing in the passport control instead of lingering in the shopping areas or reaching their flights. But in the Police HQ, no one looks at the screen, except the anthropologist, fascinated by the aesthetics of the imagery, the small moving dots that change colour, and by the fact that the border control guards are themselves being controlled. The border guards, on the other hand, don't need the screen to know when people are crowding, they can hear it through the thin walls, see it from the "aquarium" and sense the bustle. But the red and blue dots are registered and audited in the offices of "CPH Airport", the private company owning and running the entire airport complex, and the data will be used in the next negotiations with police management and Frontex about increasing flow and reducing retention on the Schengen border. 


\section{Introduction}

Border Security at Copenhagen Airport is maintained on a daily basis through the activities, intents and perspectives of a multiple and unstable assemblage of public and private actors and technologies. Two opposed types of motivations play the leading roles in this work: on the one hand, securing the national and Schengen borders against what are defined as intruders and threats and, on the other, a general pursuit of economic advantage and profit. Security plays a part in both, in itself becoming a negotiable commodity. The airport is a privileged site for analysing the blurring of responsibilities, decision-making and ongoing negotiations between different parties, because border security is produced by both public and private actors, and because the economic and the security stakes in this place are so obviously entwined and guide most interactions, as also exemplified by both Lyon's and Salter's analysis of airport security and surveillance (Lyon 2006, 2008; Salter 2008). Nevertheless, other stakes and motivations also clearly make their way into the functioning of the border security assemblage, both on the floor in the day-to-day management and production of security and control, and in the delocalized corridors of political and lobby negotiations between the various national, supranational and economic stakeholders. The interplay between diverse interests and motivations is furthermore highly unstable in that a multitude of phenomena and transformations continually come into play at all levels of the assemblage, in accordance with Deleuze \& Guattari's notion of it (1980). This makes the discernment of the processes and of the assemblage itself quite obtuse to the anthropologist's eye and other senses, and thus also quite difficult to maintain in a stable, textual form.

Blurring in this assemblage has two different facets. For one, there is a structural blurring: it is never really clear which actors are involved in border security measures and to what degree. Furthermore, the very often-conflicting agendas and interests of the involved actors are blurred, appearing on the surface as a coherent and harmonic border security apparatus. I describe this blurring of actors and interests as structural and the chapter starts by outlining the main stakeholders that produce border control and security at Copenhagen Airport, and the often-conflicting agendas that amalgamate and become indistinct in the daily application of human and technological measures of border security. A second type of blurring occurs in the particular instances where control authority is allocated, notably in every instance where a technology or a border guard decides whether to let someone pass or not. The chapter examines two such instances of control where the actual processes of decision-making and allocation of responsibilities and authority are blurred. The examples concern, for one, the negotiations for setting an acceptable threshold for facial recognition in an automated border control technology, and, secondly, the discretionary work of individual border guards in the profiling of passengers and the detection of potential threats. In both cases, I argue, these processes of decision-making constitute a blurring of border security by delocalizing, internalizing and individuating the border - respectively into the machine and into the individual border guard. So where one type of blurring concerns the unstable constituents of the assemblage, the other type concerns the blurring of the decisional actions it produces. 


\section{Borders, border studies \& blurred assemblages}

In the emergent field of critical border studies, borders are not only conceptualized as inherently geographical and physical sites of deterrence but are also seen as ephemerally enacted through a wide range of encounters and connections, notably in and between databases, ID documents, EU regulations, consulate visa redactions, migrant practices, as well as being inscribed in the bodies of travellers themselves (Adey 2009; Amoore 2006; Bigo 2002). When thinking through the eclectic notion of the assemblage, I however acknowledge that border making also does take place, localised in daily activities and encounters of various human and non-human agents, whether in passport controls, at airport counters or in asylum screening units. And this is indeed where an anthropological approach may be at its best, by bringing forth insights about the direct inter-human and human-technological workings of border production and management. A look into the everyday routines, happenstances and malfunctions of border guarding and the many actors that go into producing security on borders and producing secure borders, offers the opportunity to refine what by a more overall approach might somewhat hurriedly be described as a well-oiled and proficient system. As we shall see, the border assemblage is not a contradiction-less consistent monolithic whole, operated from far-away centres of computerized algorithmic intelligence, as other researchers of border production and security systems have also noted (e.g. Andrejevic and Gates 2014; Tsianos and Kuster 2016). When looking in more detail at the border security assemblage, it becomes apparent that it is instead composed of contradictory flows and desires, inconsistencies and absurdities.

Furthermore, the border security assemblage is constellated of an incessant stream of "small decisions" that are "conditioned, but not completely predetermined" (Rabinow 2004, 63, in Rheinberger $2009,7)$, motivated and instantiated by individual and collegial interpretations of regulations and laws, as well as by affect (Adey 2009), by algorithms, and by externalisations and contrasting desires. I therefore argue that blurring in the border security assemblage arises in this lack of overarching predetermination and coherence, and in the operation of control though a series of infinitely small decisions, both human and technological.

\section{Fieldwork on the border}

The analysis in this chapter is based on fieldwork in Copenhagen Airport over a period of five months during 2016-2017. During this fieldwork, I accompanied police and civil border guards from the Airport Border Guard Police Unit of Copenhagen Police that secure the Schengen border. For one, I sat in with the border guards as they surveyed the $A B C$ (Automated Border Control) eGates. This implied ensuring that the automation was working, scrutinizing travellers, following the passport and facial controls on a screen, overruling or "helping" the system when it had "difficulties" recognizing travellers or for other reasons did not open the eGates' glass doors, and making informed judgements when there were "hits" between controlled traveller IDs and the different national, European and international police and Schengen data bases that the recognition system was linked up to. Secondly, I sat in with agents that manually controlled passports and 
visas of travellers leaving for or arriving from non-Schengen countries. Thirdly, I followed the police agents when they made "random sampling" controls at intra-Schengen flights arriving from so-called "high-risk" European countries. I furthermore participated in the two daily briefings of the border police unit, in the short training sessions dispensed by the "DocuUnit" specialized in document fraud and falsification, and in the surveillance of various sites via CCTV and other types of screen work. Through this work, I also got insights into the general border security work undertaken by private stakeholders, the diverse surveillance technologies at play and the work of the two private companies that produce, install and maintain the $A B C$ eGates.

I did not conduct formal interviews. Rather, I discussed procedures and events over lunch and talked with border guards while we watched people, screens and movement, interrogating together what we saw. I participated in meetings and briefings, and I was myself interviewed about my work by management, by unionists, by airport security, all producing insightful materials about how they saw their work. I took handwritten notes, both by preference and because any digital technology would be seen as too intrusive, even though the field was full of such technologies. I also took occasional photos with my phone. Everyone had a phone on them; it was an accepted work tool, part of the uniform.

During fieldwork, I wore a police sign and was therefore addressed by travellers as a police officer. I observed the work of the border control agents I accompanied and took notes, and travellers appeared to classify me as a higher-ranking officer in the police hierarchy since I was ostensibly overseeing and controlling the agents. This was an unusual and challenging position to be in and a predicament that I continually analysed and tried to learn from as a constituent of the border world itself. Indeed, in some people's eyes, I was the border. This set some very particular frames for the fieldwork, notably concerning the temporal and spatial outreach of what I could perceive of the travellers' routes, hitherto and beyond this space, the nature of what they told me, depending on how they positioned me, and how I in turn could address them. In sum, the span of my perspective and thus knowledge about the travellers was narrowed down to what a police officer would hear. Indeed, as I have noted elsewhere, it is "what one participates in that becomes one's field, one's empirical object", and thus what one can get to know something about, and not the other way around (Møhl 2011, 243). It was frustrating at first but also an important acknowledgement about my analytical object and scope: I was here to get insight into police and border guard procedures and perspectives, and not to obtain an all-embracing overview of the border world nor of particular migrant itineraries and dreams for the future. Indeed, this was the position I had allotted myself and that the police management had surprisingly willingly allowed me to take up.

\section{The border security stakeholders at CPH Airport}

At Copenhagen Airport, a complex assemblage of public and private stakeholders and a multitude of minute daily human and technological actors and actions go into the daily production of border security, working 
through a structural blurring that makes it difficult to discern the distribution of authority and the conflicting agendas.

Copenhagen Airport is the main Danish airport, but also serves as an entry-point into Scandinavia and functions as the international airport for the greater part of Southern Sweden, besides constituting a Schengen entry point. The public security actors are of various national and international constellations: the Danish state represented by Copenhagen Border Police and the DocuUnit of the National Police are in charge of border control and general security, and Frontex, an EU agency, coordinates national border control and carries out sometimes unannounced checks at the airport to audit the efficiency of the national border units. Alongside these public actors, a variety of private actors contribute to the security assemblage: The airport itself is run by "CPH Airports" (CPH), a predominantly private company currently owned in majority by a Canadian holder. $\mathrm{CPH}$ and its sub-group, $\mathrm{CPH}$ Security, are in charge of all entry and exit security checks of goods and persons at the airport. ${ }^{1} \mathrm{~A}$ multitude of airline and security companies, as well as the many retailers and food stalls also carry out large measures of security and movement control and contribute to the overall security assemblage. A range of private companies provides and maintains the wide variety of technologies of control employed by both public and private actors. Outsourcing is thus an important factor of the assemblage, entangling connections and further blurring the interplay of border security practices at the airport. This to a large extent obstructs an overview of the measures of coercion at play (Adey 2009; Bloom and Risse 2016). Furthermore, a variety of security and border control technologies and practices operate both on location and at a distance as externalizations, both through data exchanges and as actual deterritorialized control activities outside the airport. So the assemblage is far-reaching, obtuse and of many formats and materialities.

Although these actors constitute an assemblage of "heterogeneous objects" that "work' together as a functional entity" (Patton 1994, 158, in Haggerty \& Ericson, 608), they are also aligned by opposing interests and desires, notably flow vs. efficient control and profit vs. legal action, as we shall see. Furthermore, if the assemblage produces operations that momentarily capture and fixate flows (ibid.), that fixation is itself a sight of friction and continued negotiation between all these different private and public actors. From the vantage point of their different desires - legal, practical, economic, temporal, individual - they produce different forms of security, and those desires and the ensuing operations are more or less tangible and simple to detect, indeed often quite obscure, hidden and in some cases, themselves only arduously subject to external scrutiny and control, notably by state, EU and NGO agencies.

With this outline of the actors and agendas, we can now look closer at the allocation of authority through particular instances where blurring takes place and is situated. To do so, I will first present the overall work of border control at the Schengen airport border.

\footnotetext{
${ }^{1} \mathrm{CPH}$ Airports employs ca. 2.500 persons, of which ca. 1.200 alone work at CPH Security.
} 


\section{Controlling the Schengen border}

Airplanes flying to $\mathrm{CPH}$ from non-Schengen countries arrive at Pier $\mathrm{C}$, coming mainly from the Middle-East and Turkey, Asia, the US and from European non-Schengen member states, such as the UK. Of the roughly 80.000 persons who daily travel in and out of CPH Airport, 19.500 cross the Schengen border. As a heightened security measure, all documents are currently scanned, meaning that no discrimination based on profiling takes place. Border control is done by police officers and by first-line civil officers who have gone through a nine weeks training program. The civil officers have only a controlling and not an executive faculty, and call in second-line police officers in case of database "hits" or questions of possible document or identity fraud. But in the checking booths, they do exactly the same work as the police officers. Because of both carrier responsibility and ID verification at check-in, persons who arrive at the airport border almost always have documents. Only in the rare cases where people seek international protection do they arrive at the border without documents to show. The work therefore mainly consists of checking that 1 ) the presented document is valid and not counterfeit or forged, 2) the holder is also the person presented in the document, i.e. not travelling with someone else's genuine document, called "impersonation" (Frontex 2013), and 3) the document and visa are valid for passage across this particular border and into Denmark and Schengen, both for Schengen citizens and third-country nationals with Schengen member-state residence permits.

The people who are intercepted at the border fall into roughly three categories: persons travelling on visas or identity cards that do not permit travel into or out of Denmark or Schengen (by far the biggest group) ${ }^{2}$; persons who have a national or international arrest warrant against them; and persons travelling on another person's genuine documents (currently the most commonly reported document fraud). ${ }^{3}$ Besides such cases, certain persons are also under national or international surveillance, their moves being "discretely monitored", which means that the border guards note down their passage but do not apprehend or engage in any direct interaction with them. Both for "discretely monitored" persons and arrest warrants, the scanned document will give rise to a "hit" in one of the connected databases. But many "hits" concern persons who are wanted but for whom the identification elements are incomplete, leading to a long series of "false hits", e.g. because a surname or part of a document number coincide with the traveller's. In all cases, a police officer will inspect the ID of the traveller and determine whether the person in question can access (or leave) Danish/Schengen territory or should be held back for further inspection, be arrested or simply denied passage.

At Copenhagen Airport, a series of Automated Border Control (ABC) eGates have recently been installed, with the main goal of heightening security from the standpoint that facial recognition technologies

\footnotetext{
${ }^{2}$ Defined as "unauthorised secondary movement of third-country nationals" (European Commission 2017). Such cases also include visa overstay.

3 Among travelers leaving Denmark/Schengen there are also many cases of overstay, either concerning visas or temporary EU residence permits. In such cases, there is a certain ambivalence among the guards about whether to let them leave the country "a bit late" or to stop them for offence, depending on the duration of the overstay. This ambivalence is related to the perplexing notion of individual intuitive discretion - skøn - that Danish police officers are required to apply in their decision making (Holmberg 2000) and that will be discussed further on.
} 
and biometric passports provide more efficient forms of control. Another motivation for installing the costly technology is to comply with the airport's request for a higher flow at the border. But in fact, according to the police officers operating on the border, the eGates are not necessarily quicker. They furthermore imply a deskillment of the human control agents with the risk of replacing them with more machines to cut down on wage expenses, as the union representatives complain. Finally, the algorithmic settings of the eGates can be - and are - negotiated between police agencies, CPH Airport and the technology developer, Vision-Box, to heighten flow, notably by lowering the threshold for the required match between the ID photo and the live facial capture at the $A B C$ eGates, as we shall see.

In the following I will examine the work of the $A B C$ eGates and the kind of blurring it represents in the production of border security. This analysis will be followed by the description of the random identity checks that border police guards are requested to carry out at intra-Schengen flights, looking for what is defined as "high-risk" travellers. In both cases, the blurring arises through mechanisms of dislocation of border security from the actual border when control and responsibility are projected respectively into an algorithmic figure and onto the individual border guard's subjective discretional interpretation and judgement, thereby obfuscating both the actual acts of decision-making and their incentives, as well as the respective influences and opposing interests of the multiple constituents of the security assemblage.

\section{Case 1: Human-technological border work}

At the $A B C$ eGates, Sandra, a civil border control agent, is checking incoming passengers from non-Schengen countries, currently from a US and a UK flight. To pass through the eGate, the passengers need to have a biometric EU (or EEA) "ePassport". The British are good at passing quickly, Sandra says. They're used to facial recognition because they have the same kind of machines at Heathrow. The passengers queue up in front of the six active gates, waiting behind a yellow line. When one has passed, a green light invites the next passenger to approach and scan his or her passport. After a while the first glass door opens and lets the passenger enter the small enclosure between the two glass doors where he/she is invited to move up to the facial scan camera and stand on the two yellow footprints on the floor. A second-line police officer steps in to indicate the right position, "if they are fooling around in there", as he says. - "Stand still, not too close". "Take off your glasses". "Take off your hat". "Remove your veil". "Look at the camera".

Sandra sits in the tall glass booth that gives an overview of the six eGates. From here she surveys people moving into the $A B C$ zone, the persons queuing and the persons inside the six eGates - scrutinizing their faces and their behaviour, checking if they suddenly change route and choose the manual passport control, keeping an eye on her screens and communicating by radio with the second-line officer and her colleagues in the other booths. She has two screens. One relates the operations and images of the ABC, how it is functioning, how each facial recognition scores, whether there are problems, for example if the passport photo and the facial scan don't match, or if the machine indicates that there are two persons in the gate. She overrides the $A B C$ and opens the exit gate manually if she can see "it is getting confused" and if she can 
identify the reasons - a person with a lot of hand luggage that is identified as two, or a person that the machine cannot recognize whereas Sandra can easily make the match between the chip and passport images on the screen and the actual face she can see through her window. She is "learning to see in $2 \mathrm{D}$ ", she says, like the machine, comparing a 2D screen photo to an actual physical 3D face. The other screen on the table indicates that the connection to the different national and international police data bases is up and running and gives alerts when there are hits - correspondences - between the $A B C$ information and the data bases. If so, the second gate does not open automatically and a fat red edge and a red triangle with a "!" appears on the image on the $A B C$ screen. In this case, Sandra reads the information provided by the data bases, assesses the nature of the correspondence, e.g. between information about an Interpol search warrant and the information provided on the person in the $A B C$ eGate via the passport. If in doubt, she calls upon the second-line officer to make an assessment and decide which action to take. With most cases, the "hit" is a false hit. But once in a while a passenger is pulled aside for further inquiry or held back if formally identified as wanted or, for example, as having to hand in a driver's licence that has been withdrawn. As such, the ABC also works as a justified site of control of offences not related to border crossing.

Sandra moves over to the outgoing $A B C$ eGate. A person of what she identifies as of East African origin arrives at the $A B C$ and stops to look. He then moves over to the manual passport control and she calls her colleagues there and tells them that he has moved away from the ABC eGate. As it turns out, he has come in from Italy and is trying to take a plane to the UK on a EU passport that is not his own. He probably decided not to risk the facial control, since the machine is better at recognizing African faces than Europeans are, she says. She asks me why that is, thinking there might be a "natural", anthropological explanation to it. She tells me that on her guard last week an airline security agent called in the police because a traveller had been stopped from boarding a Heathrow flight when trying to travel with another person's passport. The DocuUnit apprehended the traveller and ran him through the $A B C$ three times, and he almost passed once. "So sometimes the machine works better, sometimes the human eye does".

Over lunch I ask one of Sandra's colleagues what he thinks about the $A B C$ and if he sometimes works there. "No." He doesn't like it; he prefers human contact. Another officer declares he also dislikes the ABC: "The machine can't think. It's stupid and can only obey orders given by humans. It can't think ahead. I have intuition, I'm creative." And, he says, if the bosses or the airport company for some reason want a higher flow, they can just turn down the machine's vigilance with a click of a mouse, while "They can't turn down mine."

\section{Technological negotiations as a blurring of responsibilities}

When Sandra sits in her booth repeatedly looking up, out and down - up at people's faces, out over the queues and down at her screens - and taking small decisions every time she hits a button or clicks with the mouse, she is in the middle of a wide and complex assemblage where a lot of other actors of various kinds play out important roles in the control of the border. As mentioned, assemblages emerge "out of a lot of small decisions" (Rabinow 2004, in Rheinberger 2009, 7). I have already described the many public, private, 
material and immaterial actors that co-constitute the assemblage, and Sandra's and her second-line officer's actions also form minute parts of the ongoing border security assemblage. The framework for their decisions is set up by CPH Airport, by Danish Police management, by the Danish government, by EU and Frontex, and the many laws and directives they all produce; by the wide range of technologies involved in the security control; by the intentions, possibilities and interventions of the passing travellers; by the airline companies who maintain their own borders to avoid carrier responsibility fines and secure their flights; by the many private security companies they all engage; by the technology developers and maintenance groups, both private and in-house; by the weather and the time of year - in summer on sunny days, the $A B C$ camera gets sun "in its eyes" and "can't see well"; by travel trends and economic fluctuations; by union policies, and collegial connections and considerations, by their daily well-being and health-conditions; and by the interplay of all those innumerable factors and many more. There is overtly intentional conditioning - the design of the environment, protocols for action, assignment of authority - but there are very few of those intentional conditionings that actually turn into predictable and predetermined outputs.

In this blurred configuration, we can nevertheless determine some of the conditionings that define what it takes for the glass doors of the $A B C$ eGates to open and let a traveller through. This has to do with negotiating the setting of the required threshold for the facial recognition technology: CPH sets up flow detection monitoring screens in the police $\mathrm{HQ}$ on the border so the police officers in charge can see when they are slowing down the passenger flow, retaining potential customers who should instead be retained and tempted - in the shopping areas. On the background of a black-\&-white photo of the border zone, retained passengers appear in real-time as small red dots, rapidly accumulating into a red mass when flow in the manual passport control is low. People moving are presented as neutral white dots and people waiting at the $A B C$ are represented as blue dots. CPH not only makes this "dot stream" (Xovis 2017) available to the border police, as we saw above, but also transforms the dots and their respective colours into figures and graphs. They use these audits to calculate actual flow and staffing needs and allot passenger assistants ("frogs" as they are called by police staff because of their green t-shirts). More importantly, they use them to negotiate with the border police about spatial organisation, border guard staffing and in their requests for the acquisition of new technological equipment as well as the running of current technology.

The white dots moving on the monitors constitute instances of "blank figures" that can become anything (Serres 1991; Svendsen 2011), bodies without ID. They are even merchandised as "anonymous" by the developer (Xovis 2017). What counts (is counted) is not who they are, but what they might do, imbued as they are with very different types of potential: to the airport company and many shop holders, they constitute potential customers moving towards goods of consumption - when not upheld in the passport control ("red", "blue"). To the border police, the blank figures are uncertain and undetermined presences, possible threats to security until firmly ID'ed.

Police management and unions negotiate with $\mathrm{CPH}$ and with the private Portuguese firm Vision-Box and its Danish maintenance provider, Biometric Solutions, about the settings (the system acceptance threshold) of the necessary score level of facial recognition in the $A B C$, in compliance with loose Frontex 
recommendations. The "dot streams" are used by $\mathrm{CPH}$ in these negotiations. The goal is to find a balance between flow and retention, between false positives and false negatives. Frontex recommends a facial recognition score of, say 50, whereas $\mathrm{CPH}$ wants to lower it to 42 to heighten flows. ${ }^{4}$ Copenhagen Police wants to comply with Frontex recommendations and set the threshold at 50 for higher security, but the maintenance provider sets the threshold somewhere in between, for the moment. It is difficult - for all involved - to determine who has actually made the decision, but the border guards can see on the screen that people now pass with a lower recognition score - and they know that a technician from Biometric Solutions did indeed change the settings with the click of a mouse. In this negotiation, the threshold level, one simple number - e.g. " 46 " - comes to contain and encapsulate all the divergent desires and their ongoing negotiations, transforming threats, regulations, security levels, document fraud, state policies, EU directives as well as seamlessness, flow, travel experience, pleasure, human rights, and so on, into one single figure. Click! Every time a person passes through the $A B C$ eGate, several facial scan samples are made and run through the system while the doors stay closed in both ends. The algorithmically configured results are held up against the template in the passport and if the magic figure, e.g. 47 or 88 , is reached, the exit door opens automatically. The figure is somewhat arbitrary because it is the result of opposing forces but comes to encapsulate and actualize the required level of recognition, i.e. how much one is required to resemble the ID-photo of oneself in order to be considered oneself - a match! - and for the door to open.

The threshold figure is so unequivocal - it is a simple number - yet constitutes an effective blurring. For one, it is a figure that many of the involved can't see, suspended as it is between all these different actors and their on-going negotiations to find a middle ground between their differing agendas. And it is a blurring - opacification - by virtue of its oneness that signals consensus and thus nullifies all the existing differentials, tensions and contentions. But they are not resolved; they are simply glossed over. And every time the threshold figure strikes again and the door opens, the nullification of contentions and the blurring of responsibilities is replayed. Again, the "blank figure" or joker, here in the form of the threshold, represses all contention, taking it "to zero" (Serres 1991). Quite inversely, however, every time the white dots on the Police HQ monitors become blue, they effectively display and reiterate the existence of discordance and conflicting desires.

The airline companies are ambivalent, both interested in getting passengers through border control quickly so they don't derange flight schedules and on assuring both flight security and ID control, because they risk a fine and having to fly people back to their site of embarkation. They therefore do their own ID checks upon boarding. This is yet another example of decision-making responsibility being indirectly

\footnotetext{
${ }^{4}$ The recognition (or similarity) score refers to the similarity between the features of respectively the face in the $A B C$ eGate and in the passport photo. There is rarely a $100 \%$ match, but photo and face should match to a certain degree, indicating the accepted "recognition threshold". The threshold and thus the required similarity score can be raised or lowered, making it more or less easy to pass. - The figures on the screen range between 0 and 100, but do not indicate a percentage, but a score, as a Vision-Box representative repeatedly stated when the border guards talked of percent. Calling them percent, as in "you only need to look 49\% like your passport photo", is probably considered by developers and policy-makers as a misguided indication of low border security, as in "only half good enough".
} 
allocated to singular actors within the assemblage, making it more difficult to control and critique. But if the distribution of responsibilities is blurred, the assemblage is in no way a well-oiled machine. On the contrary, it is composed of diverging desires and objectives, conflicting interests and actions, and national and international and profit-seeking wishes, where specific actors often are pointed out by the others, getting fines or admonitions for mistakes and miscalculations that might be attributed to them. It is not a coherent pre-programmed whole, but a nervous and constantly fluctuating constellation of interconnected moves and desires, collisions and friction operating "across difference and distance" (Tsing 2005, 2), and appearing to both participating and external actors are opaque and blurred.

\section{Case 2: Controlling "high-risk" flights}

Border police officers regularly carry out random security and ID checks at flights arriving from Schengen countries. Such random checks are permitted within EU regulations under certain conditions, namely that they are random, which by the border police is defined as non-permanent and concerning only a certain amount of flights per week. The randomness in itself constitutes a blurring of responsibility, since all decisions are discretionary, taken by individual police officers without formal orders or protocols. The blurring thus takes the form of an individuation of border control, transferring - allocating - responsibility to the individual border guard. These checks are firmly audited by the police management, both to monitor that the work is being done and to document the number of checks in case of Frontex controls - even if the border police's work is not "to produce figures", as a police officer in charge stated. The checks are carried out by armed police officers and not civilian agents, because they are "out in the open".

Walking to Pier F where we will await the arrival of a low-cost plane from an Italian city, I accompany Hans, a short and sturdily built police agent and his new female colleague who is carrying out a random check for the first time. He is explaining the principles to her as well as the incidents with passengers that such checks sometimes give rise to. "We're looking for illegal immigrants. So we don't stop Mr. and Mrs. Hansen." While we wait, I ask him how he can see whom to pick out if he is not allowed to stop everyone. He has some tricks, he says. He can for example detect undocumented Afghan men, i.e. people who haven't been here before or don't live here, without checking their passports. "They try to blend in but always look sort of ineptsmart. You know, jeans with holes in them. Sunglasses. And there's always something with the shoes, they never fit the rest. Too fancy."

The flight arrives and they take up position at the exit of the gangway. Almost all passengers are Danish tourists coming home. But four are of African origins, arriving one by one. The first two are pulled aside, and are asked to produce their documents. They don't put up any resistance. A couple of other passengers frown or slow down, but do not intervene. A third is pulled aside and a fourth passes by the officers who are occupied checking the others. All three checked have the necessary documents. Once checked, Hans smiles to them and wishes them a safe journey. He notes down the flight number and the number of checked 
persons on an old piece of paper so the officer on duty can enter it into "the system" and the two walk off to the other end of the airport to check a flight arriving from Athens.

\section{"High-risk" profiling as a blurring of responsibilities}

So how does the randomness and the notion of "high-risk flights" configure and blur the nature of what is going on and the "production of suspicion" (Murphy \& Maguire 2015, 165)? "High risk" is used in a double sense by Frontex, as both a way to optimize resources by applying them to regions of "high risk" of migration influx (Council of the European Union 2017), i.e. an organizational sense, and geographically, when referring to specific places of origin - although "high risk" in this case ostensibly relates to routes (Kasparek 2010) and thus not to nationalities. Somewhat in accordance, at Copenhagen Airport, certain flights are defined as highrisk because they arrive from cities within Schengen that Frontex and the national authorities consider possible avenues of "illegal migrants" and refugees. They count Milan, Rome, Athens and other Greek and Italian and, to some extent, Spanish cities, i.e. intra-Schengen routes that normally are exempt of border control, but where there are high levels of arrivals of undocumented persons from the Middle East, Asia and Africa. So, when the border police randomly control such flights, i.e. submit only some flights and only some passengers to control, the notion of "high-risk" comes to relate directly to the countries of origin of the possible migrants and asylum seekers, meaning that they are in fact profiling nationalities and not just checking routes. And as a result, the persons who are effectively pulled aside when leaving the plane are all, almost per definition, people who ostensibly come from non-Schengen countries. "High-risk" thus logically, and also according to the border police officers themselves, implies that they must check people who "look high-risk", for example like they come in from an African country or from the Middle East. And as several officers have declared when I inquired about these practices and the meaning of "high-risk", this is paradoxical, because it makes them take decisions based on what effectively amounts to "racial profiling". So the law at the same time prohibits and actively installs a system of racial and ethnic profiling. Furthermore, even if they might want to contest the legality and ethics of these random checks and the fact that they are making them "behave racist", ${ }^{5}$ the unit is as mentioned required to produce a certain number of random checks per week for future Frontex and management audits, producing a classical "feedback loop" logic where only certain groups are controlled and where the figures therefore concern only these groups, thereby both reinforcing and justifying future controls of the same target groups (cf. Fassin 2013; Holmberg 2000).

From the perspective of a security assemblage analysis, it is the configuration of the notion of "high risk" that merits attention, co-produced as it is by a number of different national and supra-national actors that more or less overtly contribute to its meaning, leading to very particular and discriminatory effects in the control of movement and the profiling of travellers. Furthermore, the principle of "randomness"

\footnotetext{
${ }^{5}$ As one interlocutor despairingly noted, "If I wasn't a racist before, this work is making me into one". What she was referring to was not that her personal opinion vis-a-vis certain ethnic groups was changing, but that she was being asked to apply higher vigilance and suspicion to certain groups than to others, in what one could thus define as a case of "systemic racism".
} 
displaces the choice-making on to the individual police officers who come to determine which flights and which passengers are to be seen as "high-risk", relocating responsibility onto the notorious " 6 th sense" and "gut feeling" of the individual officer, i.e. the legally installed discretion or hunch (skøn) (Holmberg 2000, 2003; Brouwer et.al. 2018). This ultimately places any executive act within the field of subjective, intuitive and therefore impalpable, often unacknowledged and un-verbalised individual interpretation and discernment. So ultimately, "high-risk" and random checks contribute to a virtual blurring of the premises for and the production of border security at the airport.

\section{Conclusions}

The security assemblage operating on the heterogeneous border of Copenhagen Airport is made up of a complex of varying desires for both flow and retention, of contrasting political-organizational objectives and practical feasibilities. These are desires to which we have only a partial insight, both because of the transfer and blurring of responsibilities (Hönig 2014) and because of the way these desires continuously interact and contradict one another, making the functioning at every moment fluctuating and unsystematic. With Ulrich Beck's term, we could define this blurring as an "organized irresponsibility" (2009), where the definitions of high-risk and of the necessary recognition thresholds are delegated to a variety of singular actors - in the two examples, facial recognition algorithms and individual officers' discretion - that are difficultly identifiable. The recognition threshold of the $A B C$ technology blurs the conflicts between public and private actors, as well as the unofficial negotiations between their conflicting agendas, while its oneness ostensibly signifies a perfect consensus between the actors. The "high-risk" notion blurs the responsibility of implementing national and EU migration policies by assigning responsibility and decisions to individual officers and their personal tactics, while imposing certain selective logics. The notion comes to produce very problematic procedures of discrimination, also in the eyes of those who are implementing them in their daily work.

Such blurring makes the security assemblage difficult to assess and to control. No one ever really knows who is involved in producing border security in the different sites and how strongly they influence the procedures according to their variegated agendas. This is a predicament for both authoritative agencies on various levels, for NGOs wishing to protect human mobility and privacy rights (Bloom \& Risse 2014) and for individuals trying to make their way through the security assemblage.

It is also a predicament for the researcher wishing to gain an insight into the current state of affairs of local border work. But by following specific procedures in the daily work of border security agents who individually take a multitude of "small decisions" in their choice-making and interaction with the automated machines, it does become clear that there is no overarching predetermined and coherent border security machine at work. Some particular lines of force nevertheless stand out, both about the nature of the blurredness and about the redistribution of responsibilities, as the analysis of the examples has shown. 
And finally, it is a predicament for the people and actors engaged in the daily work on the floor. The border guards feel their authority is being undercut and their know-how is waning as they become deskilled by machines that take over the scrutinizing, that can only re-cognize and not cognize, and that can't think creatively. The machine does not work through discretion, but acts on a clear albeit arbitrarily set figure, and its vigilance level can be lowered by the click of a mouse. Who actually sets that figure is never really clear. The border guards can turn off the machine - and they sometimes do when it starts "glitching", malfunctions in one gate "spreading to the others like a virus" - but when it is running, they can only assist it. The airline companies administer the work of border control without clear orders and with the risk of penalties if they transport persons who are not admissible. And travellers end up either caught in awkward and secluded locations or without the possibility to ask for the international protection to which they would be entitled, and the organizations that are trying to ensure that such rights are protected stand helpless. Possibly, and not surprisingly, the only actors who seem to pull an advantage from the incongruities, the blurring and the lack of clear responsibilities are the private contractors who carry out preventive control for the airline companies, the airport holdings that own and design airport spaces as vast shopping malls and sites of leisure, pleasure and new shopping experiences, as well as the private agencies that provide the vast array of costly technological infrastructures applied in security, surveillance, flow monitoring and border control. Security and border control certainly does slow down the flow of bodies-as-potential-customers - turning mobile white dots into reds blurbs - and thereby blemishes the performance of the airport as a site of pleasure and seamless movement provided by a coherent body. But going through security and border control at the same time becomes - and is commodified as - a reassuring and selective quality inherent to that exclusive pleasure and movement.

\section{Acknowledgements}

The research project, Biometric technologies and the enskillment of vision in border control, with fieldworks in Denmark, Gibraltar and Spain, has been financed by the Velux Foundation, and I would like to thank the foundation for their support. The project is part of a larger collaborative project, Biometric Border Worlds.

\section{Bibliography}

Adey, Peter. "Facing airport security: Affect, biopolitics, and the preemptive securitisation of the mobile body." Environment and Planning D: Society and Space 27 (2009): 274-296.

Amoore, Louise. "Biometric borders: Governing mobilities in the war on terror." Political Geography 25 (2006): 336-51.

Andrejevic, Mark and Kelly Gates. "Big Data Surveillance: Introduction." Surveillance \& Society 12, no. 2 (2014): 185-196. 
Beck, Ulrich. "Critical Theory of World Risk Society: A Cosmopolitan Vision." Constellations 16, no. 1 (2009): 3-22.

Bigo, Didier. "Security and immigration: toward a critique of the governmentality of unease." Alternatives, 27 (2002): 63-92.

Bloom, Tendayi and Verena Risse. "Examining hidden coercion at state borders: why carrier sanctions cannot be justified." Ethics \& Global Politics 7, no. 2 (2014): 65-82.

Brouwer, Jelmer, Maartje van der Woude and Joanne van der Leun. "( $\mathrm{Cr}$ )immigrant framing in border areas: decision-making processes of Dutch border police officers." Policing and Society 28, no. 4 (2017): 448-63.

Council of the European Union. Frontex draft Programming Document 2018 - 2020, http://www.statewatch.org/news/2017/feb/eu-frontex-work-programme-2018-20.pdf, accessed June 26, 2017.

Deleuze, Gilles, and Félix Guattari. Mille plateaux (Capitalisme et schizophrénie II). Paris: Éditions de Minuit, 1980.

European Commission. "Commission Recommendation of 12.5.2017 on proportionate police checks and police cooperation in the Schengen area", http://www.statewatch.org/news/2017/may/eu-comrecommendation-police-checks-final-17-2923.pdf, accessed July 16, 2017.

Fassin, Didier. Enforcing Order: An Ethnography of Urban Policing. Cambridge: Polity Press, 2013.

Frontex. "Frontex Evaluation Report 2013 - Joint Operation METEOR 2013 - Air Border Cooperation". Warsaw: Frontex, 2013.

Haggerty, Kevin D. and Richard V. Ericson. "The surveillant assemblage." British Journal of Sociology 51, no. 4 (2000): 605-22.

Holmberg, Lars. "Discretionary Leniency and Typological Guilt: Results from a Danish Study of Police Discretion." Journal of Scandinavian Studies in Criminology and Crime Prevention 1, no. 2 (2000): 179194.

Holmberg, Lars. Policing stereotypes: A qualitative study of police work in Denmark. Glienicke/Berlin, Madison/Wisconsin: Galda + Wilch Verlag, 2003.

Hönig, Patrick. "States, Borders and the State of Exception: Framing the Unauthorised Migrant in Europe." Etnofoor 26, no. 1 (2014): 125-45.

Kasparek, Bernd. "Borders and Populations in Flux: Frontex's Place in the European Union's Migration Management". In The Politics of International Migration Management, edited by M. Geiger and A. Pécoud, 119-40. London: Palgrave Macmillan UK, 2010.

Lyon, David. "Airport screening, surveillance, and social sorting: Canadian responses to 9/11 in context." Canadian Journal of Criminology and Criminal Justice 48, no. 3 (2006): 397-411.

Lyon, David. "Filtering flows, friends, and foes: global surveillance." In Politics at the Airport, edited by Mark B. Salter, 29-49. Minneapolis: Univ. of Minnesota Press, 2008.

Murphy, Eileen and Mark Maguire. "Speed, Time and Security: Anthropological Perspectives on Automated Border Control." Etnofoor 27, no. 2 (2015): 157-77.

Møhl, Perle. "Mise en scène, Knowledge and Participation: Considerations of a Filming Anthropologist." Visual Anthropology 24, no. 3 (2011): 227-45.

Rheinberger, Hans-Jörg. "Recent science and its exploration: the case of molecular biology." Studies in History and Philosophy of Biological and Biomedical Sciences 40 (2009): 6-12. 
Salter, Mark B. "The Global Airport: Managing space, speed, and security." In Politics at the Airport, edited by Mark B. Salter, 1-28. Minneapolis: Univ. of Minnesota Press. 2008.

Serres, Michel. Rome: The Book of Foundations. Stanford: Stanford University Press, 1991.

Svendsen, Mette N. "Articulating potentiality: Notes on the delineation of the blank figure in human embryonic stem cell research." Cultural Anthropology 26, no. 3 (2011): 414-37.

Tsianos, Vassilis S. and Brigitta Kuster. "How to liquefy a body on the move: Eurodac and the Making of the European Digital Border." In EU Borders and Shifting Internal Security, edited by R. Bossong \& H.

Carrapico, 45-63. Springer International Publishing, 2016.

Tsing, Anna. Friction: an ethnography of global connection. Princeton, N.J: Princeton University Press, 2005. Xovis. https://www.xovis.com/en/xovis/, accessed August 18, 2017. 